\title{
Ecological aspects of Rhodnius nasutus Stål, 1859 (Hemiptera: Reduviidae: Triatominae) in palms of the Chapada do Araripe in Ceará, Brazil
}

\author{
Fernando Braga Stehling Dias, Cláudia Mendonça Bezerra', \\ Evandro Marques de Menezes Machado², Cláudio Casanova ${ }^{3}$, Liléia Diotaiuti/ ${ }^{+}$
}

Laboratório de Triatomíneos e Epidemiologia da Doença de Chagas, Centro de Pesquisas René Rachou-Fiocruz, Av. Augusto de Lima 1715, 30190-002 Belo Horizonte, MG, Brasil 'Secretaria do Estado da Saúde do Ceará, Fortaleza, CE, Brasil ²Universidade Federal de

Ouro Preto, Ouro Preto, MG, Brasil '3Superintendência de Controle de Endemias do Estado de São Paulo, São Paulo, SP, Brasil

The aim of this work is to present aspects related to the ecology of Rhodnius nasutus Stall, 1859 in palms from Chapada do Araripe in Ceará, Brazil. The following five species of palms were investigated: babaçu (Attalea speciosa), buriti (Mauritia flexuosa), carnaúba (Copernicia prunifera), catolé (Syagrus oleracea) and macaúba-barriguda (Acrocomia intumescens). Fifth palms were dissected (10 specimens for each species). The overall infestation index was 86\%, with a total of 521 triatomines collected. The Trypanosoma cruzi Chagas, 1909 Index was $16.8 \%$ and two insects presented mixed infection with Trypanosoma rangeli Tejera, 1920. A precipitin test showed that $\mathrm{R}$. nasutus from palms of Chapada do Araripe are associated with opossum and bird although other possible bloodmeals were observed. Our results showing a high index of infestation of the palms as well as T. cruzi infection, the association of $\mathrm{R}$. nasutus with the most diverse species of palms and proximity of these palms to houses demonstrate the importance of this area for sylvatic T. cruzi transmission and suggest the need for epidemiological surveillance in the region of the Chapada do Araripe.

Key words: Rhodnius nasutus - palms - Chapada do Araripe - Brazil

Currently, a total of 141 species of triatomines are recognised (Galvão et al. 2003, Forero et al. 2004, Galvão \& Ângulo 2006, Costa et al. 2006, Costa \& Felix 2007, Martínez et al. 2007, Bérenger \& Blanchet 2007) and are distributed geographically from the Southern United States to Argentina. Brazil has the greatest triatomine diversity, with 60 species recorded (Galvão et al. 2003, Costa \& Felix 2007). Based on their capacity to colonise human habitations and their high degree of antropophily, some of these triatomines are epidemiologically linked to Chagas disease. Some triatomine species are also vectors of another trypanosomatid, Trypanosoma rangeli, especially those belonging to the genus Rhodnius (D’Alessandro \& Hincapie 1986).

The diversity of triatomine ecotopes includes palm trees, which are natural habitats for Rhodnius spp. (Gamboa 1961, Pifano 1973, Barretto 1979, Lent \& Wygodzinsky 1979, Diotaiuti \& Dias 1984, Romaña et al. 1999, Teixeira et al. 2001 Abad-Franch et al. 2001, Gurgel-Gonçalves et al. 2004). It has been suggested that microclimate plays an important role in establishing a stable relationship between Rhodnius species and palms (Lorenzo et al. 2003), influencing the adaptation of the bugs to different palm genera (Diotaiuti et al. 2005).

Financial support: Fapemig, CNPq, CPqRR-Fiocruz + Corresponding author: diotaiuti@cpqrr.fiocruz.br Received 15 August 2008

Accepted 8 December 2008
The geographical distribution of Rhodnius nasutus, Stål, 1859 is restricted to the Northeastern (NE) region of Brazil, including the states of Ceará, Maranhão, Paraíba, Pernambuco, Piauí and Rio Grande do Norte (Lucena \& Lima-Borba 1977, Carcavallo et al. 1998, Galvão et al. 2003). This species is considered to be of secondary importance in the transmission of T. cruzi (Alencar 1987).

The objective of the present work is to study the ecology of $R$. nasutus in association with different palm species in the Chapada do Araripe from Ceará, as well as to verify the prevalence of trypanosome infection on the captured triatomines.

\section{MATHERIALS AND METHODS}

Study area and triatomine sampling - Triatomines were obtained from locations within the Chapada do Araripe in Ceará, including the municipalities of Barbalha $\left(7^{\circ} 18^{\prime} \mathrm{S} 38^{\circ} 55^{\prime} \mathrm{W}\right)$, Crato $\left(7^{\circ} 14^{\prime} \mathrm{S} 39^{\circ} 24^{\prime} \mathrm{W}\right)$, Juazeiro do Norte ( $\left.7^{\circ} 12^{\prime} \mathrm{S} 39^{\circ} 18^{\prime} \mathrm{W}\right)$, Missão Velha $\left(7^{\circ} 15^{\prime} \mathrm{S} 39^{\circ} 08^{\prime} \mathrm{W}\right)$ and Santana do Cariri ( $7^{\circ} 11^{\prime} \mathrm{S} 39^{\circ} 44 \mathrm{~W}$ ) (Fig. 1). The Chapada do Araripe is located in the Cariri micro-region, a transition area situated between "cerrado" and "caatinga" that includes ecological elements of the Amazonian forest, Atlantic forest and "cerrado" (Bagnoli 1998). Human activities are based on subsistence agriculture, principally the cultivation of beans, manioc, maize and sugar cane. The region has 307 springs or water sources, which explain its high humidity and botanical diversity (Bagnoli 1998). The annual rainfall is approximately $920 \mathrm{~mm}$ and the temperature varies from $24-26^{\circ} \mathrm{C}$, with a minimum of $21-23^{\circ} \mathrm{C}$ in July and a maximum in January of $25-27^{\circ} \mathrm{C}$. 


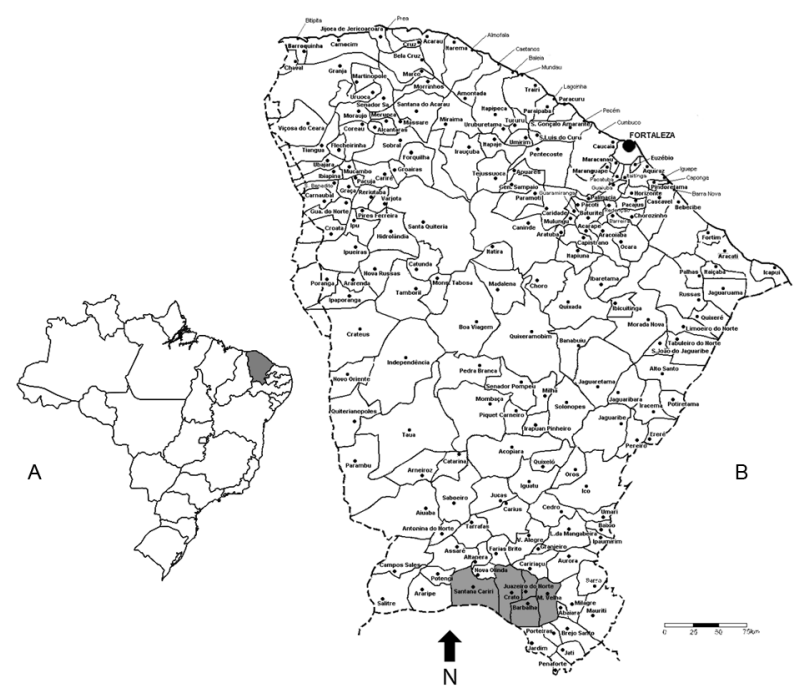

Fig. 1: A: map of Brazil with Ceará shown in grey; B: map of state of Ceará with the municipalities surveyed in grey.

The triatomines were collected from 14 March-6 April 2006 with the participation of personnel from the Ceará State Health Service (SESA-CE). Palms were identified based on characteristics described by Henderson et al. (1995) and Lorenzi et al. (1996, 2004). Samples were obtained from 10 specimens of the following five palm species: babaçu (Attalea speciosa), buriti (Mauritia flexuosa), carnaúba (Copernicia prunifera), catolé (Syagrus oleracea) and macaúba-barriguda (Acrocomia intumescens).

A field data form was completed for each palm, including information such as the date and time the tree was cut down, the species and size of the palm, associated fauna and leaf axil temperature. Immediately after being cut down, palms were dissected by cutting the base of the foliar sheath. Each leaf was removed carefully and searched thoroughly for the presence of triatomines. Searches were also performed in the bracts, fruit bunches and stems. All sampling was authorised by the IBAMA (authorisation 005/2006, process 02007.002599/2005-02).

The triatomines captured on each of the five palm species constituted a study colony. A positive palm was defined as one harbouring at least one triatomine specimen or with exuvia or eggs present.

Trypanosome infection - Fresh faeces of collected triatomines were submitted to parasitological examination by diluting them in a drop of $0.15 \mathrm{M}$ saline solution to verify trypanosome infection. This drop was placed on a slide under a cover slip and examined under an optical microscope at a magnification of $160 \mathrm{X}$ (procedure carried out in the laboratory of SESA-CE).

Additionally, examination for the presence of T. rangeli in the haemolymph was performed in the Laboratório de Triatomíneos e Epidemiologia da Doença de Chagas of the Centro de Pesquisa René Rachou, Fiocruz, Belo Horizonte (LATEC), since Rhodnius spp is considered a natural vector of this trypanosome. Only triatomines positive for the examination of the gut and survivors that reached LATEC had their legs sectioned and microdrops (approximately $10 \mu \mathrm{L}$ ) of haemolymph placed on a slide under a cover slip. This material was examined under an optical microscope at a magnification of 160X. From the positives haemolymphs, immediate isolation of the parasites was carried out in culture medium and sterile conditions. All procedures were performed according to Dias et al. (2007).

Bloodmeal sources - A sample of triatomines collected in the field had their intestinal contents removed and transferred to slides of filter paper. The life cycle stage and code of the palm where it was isolated from were noted for each insect. After drying, the intestinal contents of each bug were stored at room temperature individually in plastic bags. Precipitin tests in capillary tubes were performed according to the technique described by Siqueira (1960). Each sample was tested against anti-sera of bird, dog, opossum, cat, human, pig and rodent, all of which were produced in rabbits.

\section{RESULTS}

Index of infestation - Summarised data on the infestation of the different palm can be found in Table I. The mean time for complete dissection of palm crowns varied from $35 \mathrm{~min}$ for C. prunifera to $120 \mathrm{~min}$ for A. speciosa.

Population density - All 521 triatomines were collected (71 adults and 450 nymphs) and identified as $R$. nasutus based on morphological characteristics (Lent \& Wygodzinsky 1979). However, the specimens collected on C. prunifera were reddish, as in the original species description, while those from the other species of palms were chestnut-coloured (Fig. 2).

The relative results and population density of fieldcollected triatomines are summarised in Table II. Fourth and fifth instar nymphs were the most frequently encountered life cycle stages with 161 and 146 specimens collected, respectively. Adult triatomines represented $13.6 \%$ of the specimens collected, while $86.4 \%$ were nymphs. No viable eggs or eggshells were found in any of the palms studied. Two palms (1 babaçu and 1 catolé) presented with the highest triatomine densities (73 and 77 R. nasutus, respectively), increasing the median values for these groups of palms considerably.

\section{TABLE I}

Absolute and relative values of triatomine infestation for each palm species

\begin{tabular}{lcc}
\hline \multirow{2}{*}{ Palm/Species } & \multicolumn{2}{c}{ Infestation } \\
\cline { 2 - 3 } & $\begin{array}{c}\text { Absolute } \\
\text { value }\end{array}$ & $\begin{array}{c}\text { Relative } \\
\text { value } \%\end{array}$ \\
\hline Babaçu $($ A. speciosa) & $10 / 10$ & 100 \\
Buriti $($ M. flexuosa) & $09 / 10$ & 90 \\
Carnaúba $($ C. prunifera $)$ & $08 / 10$ & 80 \\
Catolé (S.oleracea) & $09 / 10$ & 90 \\
Macaúba-barriguda $($ A. intumescens) & $07 / 10$ & 70 \\
\hline Total & $43 / 50$ & 86 \\
\hline
\end{tabular}


Trypanosome infection - Of the triatomines collected, $382(77.3 \%)$ were subjected to examination by abdominal compression for verification of trypanosomatid infection. Sixty-four (16.8\%) of the 382 triatomines examined were infected with T. cruzi (Dias et al. 2007). The overall numbers of triatomines captured, examined and found to be infected are shown in Table III. The only species of palm in which no infected insects were found was carnaúba. Babaçu palms had both the highest ratio of trees containing $R$. nasutus infected with trypanosomatids $(50 \%)$ and the highest prevalence of infected triatomines $(21.5 \%)$. Two (7.7\%) of the 26 R. nasutus whose haemolymph was analysed were infected with $T$. rangeli, one having been collected from a buriti and the other from a catolé. These two insects presented with mixed infections (both $T$. cruzi and T. rangeli) while the others had only T. cruzi (Dias et al. 2007).

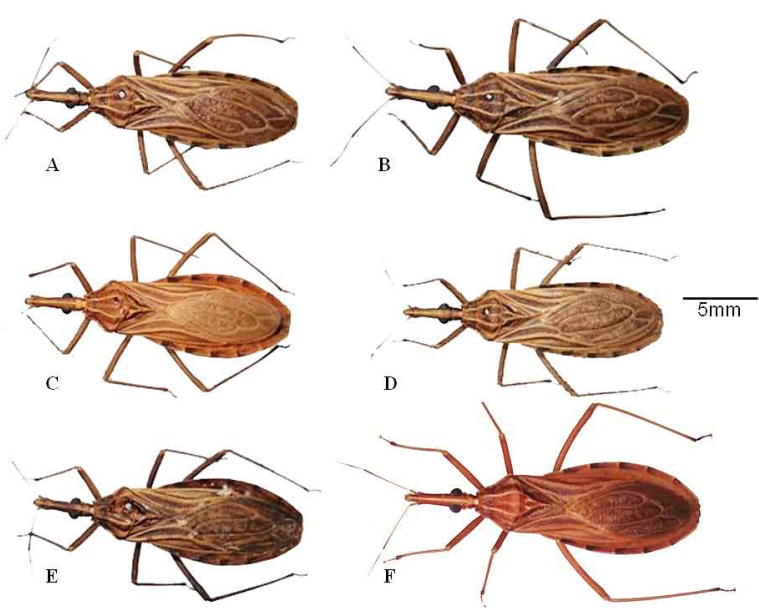

Fig. 2: females of Rhodnius nasutus collected on the five palm in Chapada do Araripe, state of Ceará, Brazil, showing chromatic difference. A: babaçu; B: buriti; C: carnaúba; D: catolé; E: macaúba-barriguda; $\mathrm{F}:$ R. nasutus presenting typical coloration according to the species' description (specimen collected in state of Ceará).
Precipitin reaction - One hundred fifty-two fieldcollected $R$. nasutus had their bloodmeals examined. The precipitin reaction was positive in 70 insects (46.1\%), the remainder $(82 ; 53.9 \%)$ of which had insufficient or non-reactive material. Opossum and birds were the only hosts detected $(34.9 \%$ and $13.2 \%$, respectively). Three specimens had fed on these two hosts (Table IV). A positive reaction to human anti-sera was not observed in the samples tested.

Fauna associated with triatomines in the palms - The vertebrate fauna found in the palms during dissection and constituting potential bloodmeal sources for triatomine bugs are listed in Table V. Several species of arthropods were also present, including ants, termites, cockroaches, beetles, grasshoppers, crab spider (Iridopelma spp.), other Heteroptera, pseudoscorpions and several centipedes, which could not be identified further.

\section{DISCUSSION}

Most information regarding triatomines of Ceará was compiled by Alencar (1987), who reported that $77.8 \%$ of babaçus and macaubeiras in Crato were infested with $R$. nasutus associated with opossums and bats, albeit at low triatomine densities $(n=9)$. According to the National Triatomine Survey (Silveira et al. 1984), all municipalities in the present study, except Santana do Cariri, had been notified of the presence of $R$. nasutus inside houses and this species was considered as the fourth most common species in Ceará by Alencar.

Sarquis et al. (2004) used live bait traps (Noireau et al. 2002) to examine 523 specimens of carnaúba, the only palm species in Jaguaruana, an area of caatinga in NE Ceará. These authors found $R$. nasutus in $24.9 \%$ of these palms, with $25 \%$ of the triatomines infected.

Sarquis et al. (2006) showed, also in Jaguaruana, that the preferred material of $R$. nasutus was palm tree straw used as roofing for henhouses. This was determined while they evaluated what peridomicile ecotopes are the best suited for installation and development of the Chagas disease vectors. Moreover, colonies of $R$. nasutus were found with up to 50 insects in the peridomi-

\section{TABLE II}

Numbers of triatomines collected according to life cycle stage and palm species in Chapada do Araripe, Ceará, Brazil (March-April 2006)

\begin{tabular}{|c|c|c|c|c|c|c|}
\hline \multirow[b]{2}{*}{ Instar } & \multicolumn{6}{|c|}{ Number of triatomines - Species of palm } \\
\hline & Babaçu & Buriti & Carnaúba & Catolé & Macaúba & Total \\
\hline I & 03 & 0 & 5 & 5 & 3 & 16 \\
\hline II & 27 & 0 & 2 & 1 & 2 & 32 \\
\hline III & 50 & 3 & 1 & 15 & 26 & 95 \\
\hline IV & 63 & 8 & 1 & 68 & 21 & 161 \\
\hline V & 51 & 6 & 4 & 82 & 3 & 146 \\
\hline Female & 12 & 1 & 5 & 11 & 2 & 31 \\
\hline Male & 18 & 1 & 6 & 9 & 6 & 40 \\
\hline Total (\%) & $224(43.0)$ & $19(3.6)$ & $24(4.6)$ & $191(36.7)$ & $63(12.1)$ & $521(100)$ \\
\hline $\operatorname{med}\left(\mathrm{Q}_{1} ; \mathrm{Q}_{3}\right)^{a}$ & $19(7 ; 28)$ & $1(1 ; 2.25)$ & $2,5(0.75 ; 4.25)$ & $11,5(6.25 ; 26.5)$ & $2,5(0.0 ; 9.5)$ & $4(0.0 ; 9.5)$ \\
\hline
\end{tabular}

$a$ : median (1st quartile; 3 th quartile). 
cile. The constant presence of $R$. nasutus around houses, along with Chagas Disease Program Control (PCDCh) records, reinforces its potential as a vector of $T$. cruzi to humans and between wild and synantropic animals.

All triatomines collected in carnaúbas were reddish,

\section{TABLE III}

Triatomines captured, examined and found infected with trypanosomatids, according to species of palm from Chapada do Araripe, Ceará, Brazil (March-April 2006)

\begin{tabular}{lccc}
\hline Palm & $\begin{array}{c}\text { Triatomines } \\
\text { captured }(\%)\end{array}$ & $\begin{array}{c}\text { Triatomines } \\
\text { examined }(\%)\end{array}$ & $\begin{array}{c}\text { Triatomines } \\
\text { infected }(\%)\end{array}$ \\
\hline Babaçu & $224(43.0)$ & $144(64.4)$ & $31(21.5)$ \\
Buriti & $19(3.6)$ & $15(79.0)$ & $1(6.8)$ \\
Carnaúba & $24(4.6)$ & $16(66.7)$ & 0 \\
Catolé & $191(36.7)$ & $148(77.5)$ & $29(19.6)$ \\
Macaúba & $63(12.1)$ & $59(93.7)$ & $3(5.0)$ \\
\hline Total & $521(100)$ & $382(73.3)$ & $64(16.8)$ \\
\hline
\end{tabular}

as in the original species description according to Lent and Wygodzinsky (1979), while those in the other palm species were chestnut-coloured. Gaunt and Miles (2000) suspected that variation in triatomine colour patterns, particularly those of certain Rhodnius species, may be influenced by habitat (e.g., the palm species on which they occur). Our field observations support this theory, as colouration of $R$. nasutus (nymphs and adults) corresponded exactly to that of the stems and base of the fronds, providing camouflage for the insects.

Each palm species had a distinct architecture and represented a unique ecosystem. However, in all five species, the great majority of triatomines were captured within the foliar sheath and sometimes at the base of the petiole.

Palms of the genus Attalea provide that have favourable ecotopes for several species of triatomines, particularly those of the genus Rhodnius, have already been studied in several regions of Brazil and other countries of South and Central America (Barretto 1979, Romaña et al. 1999, Teixeira et al. 2001, Diotaiuti et al. 2005,

\section{TABLE IV}

Bloodmeal source identified by precipitin reaction in Rhodnius nasutus, according to palm species and life cycle stage, for specimens collected in Chapada do Araripe, Ceará

\begin{tabular}{|c|c|c|c|c|c|c|c|}
\hline & & \multicolumn{6}{|c|}{ Results } \\
\hline & & Bird & $\begin{array}{c}\text { Bird + } \\
\text { Opossum }\end{array}$ & Opossum & $\begin{array}{c}\text { Material } \\
\text { insufficient }\end{array}$ & Non-reactive & $\begin{array}{c}\text { Examined/ } \\
\text { Reactive (\%) }\end{array}$ \\
\hline \multirow[t]{2}{*}{ Babaçu } & nymphs & 2 & 1 & 14 & 5 & 5 & $106 / 53(56.2)$ \\
\hline & adults & 3 & 0 & 33 & 13 & 30 & \\
\hline \multirow[t]{2}{*}{ Buriti } & nymphs & 0 & 0 & 0 & 0 & 0 & $2 / 0(0)$ \\
\hline & adults & 0 & 0 & 0 & 0 & 2 & \\
\hline \multirow[t]{2}{*}{ Carnaúba } & nymphs & 0 & 1 & 3 & 0 & 0 & $9 / 5(45)$ \\
\hline & adults & 1 & 0 & 0 & 3 & 1 & \\
\hline \multirow[t]{2}{*}{ Catolé } & nymphs & 2 & 0 & 0 & 1 & 1 & $25 / 9(36)$ \\
\hline & adults & 7 & 0 & 0 & 4 & 10 & \\
\hline \multirow[t]{2}{*}{ Macaúba } & nymphs & 0 & 0 & 0 & 3 & 1 & $10 / 3(30)$ \\
\hline & adults & 2 & 1 & 0 & 1 & 2 & \\
\hline \multirow[t]{2}{*}{ Total } & nymphs $^{a}$ & 4 & 2 & 17 & 9 & 7 & $152 / 70(46.1)$ \\
\hline & adults $^{a}$ & 13 & 1 & 33 & 21 & 45 & \\
\hline
\end{tabular}

$a$ : total number of triatomines reactive to bird $=20$ ( 6 nymphs and 14 adults), and to opossum $=53$ (19 nymphs and 34 adults).

TABLE V

Absolute frequencies of the possible bloodmeal sources for triatomines observed in different species of palms from Chapada do Araripe, Ceará, Brazil (March-April 2006) ${ }^{a}$

\begin{tabular}{|c|c|c|c|c|c|c|c|}
\hline Palm & Amphibian & $\begin{array}{l}\text { Bird or indications of } \\
\text { their presence }{ }^{b}\end{array}$ & Snake & Opossum & Lizard & Bat & Total \\
\hline Babaçu & 2 & 7 & 0 & 1 & 5 & 2 & 17 \\
\hline Buriti & 2 & 4 & 1 & 0 & 1 & 3 & 11 \\
\hline Carnaúba & 0 & 2 & 0 & 0 & 3 & 1 & 6 \\
\hline Catolé & 1 & 3 & 0 & 0 & 6 & 0 & 10 \\
\hline Macaúba & 1 & 2 & 0 & 0 & 3 & 1 & 7 \\
\hline Total & 6 & 18 & 1 & 1 & 18 & 7 & 51 \\
\hline
\end{tabular}

$a$ : 10 palms of each species; $b$ : presence of abandoned nests and/or discarded feathers. 
Sanchez-Martin et al. 2006). Romaña et al. (1999) investigated possible sylvatic ecotopes of Rhodnius pallescens Barber, 1932 in Panama among five palm species and identified this palm genera (Attalea butyracea) as the principal ecotope of this triatomine in the region, based on its high density in this palm. In the present study, babaçu was the palm with the highest infestations of $R$. nasutus and overall triatomine density in the Chapada do Araripe region, consistent with a large diversity of potential bloodmeal sources (birds and mammals). The high density may be explained by the presence of one opossum with her offspring (Didelphis albiventris) in the babaçu. Similar findings were obtained by Barretto (1979) in Uberaba, Minas Gerais, in babaçus infested with Rhodnius neglectus Lent, 1954. These triatomines were captured on the trunks of the palms, under the frond sheaths, although it appears that among the palm species studied, babaçu presented the greatest number of bugs in the seed pods and bracts. The type of insertion of the fronds of babaçu in the stem apparently constitutes a highly protected environment, probably allowing greater microclimatic stability and shelters for animal hosts of $T$. cruzi and refuges for triatomines (Lorenzo et al. 2003).

However, macaúba-barriguda was the palm species with the lowest infestation rate in this study $(70 \%)$. Diotaiuti and Dias (1984) studied another species of macaúba palm (formerly Acrocomia sclerocarpa, now Acrocomia. aculeata) in the periphery of Belo Horizonte, Minas Gerais, and found an infestation rate of $60.5 \%$ for $R$. neglectus, and that some palms were also being inhabited by Panstrongylus megistus. Barretto (1979) showed that A. aculeata was infested by different triatomines, but especially by R. neglectus in the states of São Paulo and Minas Gerais. In Argentina, this species seems to also be important as Triatoma sordida Stål, 1859 ecotope (Bar \& Wisnivesky-Colli 2001). Microclimatic variation in the leaf axil of this palm species was wide (Lorenzo et al. 2003). With a high dispersion over South America, these data showed a very important ecological ecotope of $A$. aculeata for the Chagas disease vectors.

Although the infestation rate of buritis was high $(90 \%)$, triatomine density was the lowest among all the palm species examined (only 19 specimens). This species was the hardest to sample for triatomines for two reasons: (i) its large size, with very large foliar bases that required the trunk to be manipulated throughout its dissection, and (ii) the localities in which it occurred: buritis grow in waterlogged soils or swampy areas ("brejos"), hence the popular name of "palmeira-do-brejo" or swamp palm. Our results might also have been influenced by: (i) the fact that buriti fronds are fan-shaped, the petioles forming a type of "vase" in which water accumulates, providing unsuitable microhabitats for the bugs, and (ii) since these palms occur in swampy soils and have open crowns, the interiors of some of the petioles that are very close to the leaf axil became filled with mud the moment these palms are cut down, precluding the search for triatomines.

The carnaúba palm has already been considered as a natural ecotope of $R$. nasutus. Silva and Silva (1989) looked at the influence of temperature on the biology of this triatomine and found its life cycle to be much shorter at $30^{\circ} \mathrm{C}$ than at $25^{\circ} \mathrm{C}$. The insects also ingested more blood and had higher fecundity at the higher temperature. Given that conditions in carnaúba palms are similar to those maintained in the laboratory in this study, the high degree of adaptation of $R$. nasutus to this palm might allow it to survive in an environment that is not possible for other species of triatomines. The availability of bloodmeal sources and refuges are probably important determinants of triatomine density. Carnaúba was the only palm species that did not present infected triatomines. The architecture of the carnaúba palm provides fewer triatomine refuges than that of any other species examined and may also limit the numbers of vertebrates that seek shelter in its crown, reducing the T. cruzi infection rate. This palm was restricted to sandy soils at lower elevations (about $360 \mathrm{~m}$ ), often in areas that are flooded during the rainy season, sunny and with high temperatures.

Although the infestation rate of buritis and catolés was the same (90\%), the two species differed significantly with respect to their population densities, the latter being the palm from which the second highest number of R. nasutus was collected (triatomine infection rate being $19.6 \%$ ). Due to the limitations of the antisera battery used for precipitin testing, it was not possible to determine the importance of many of the arthropod or vertebrate animals found in palm crowns as haemolymph or blood sources. One nest of a kiskadee flycatcher (Pitangus sulphuratus) found in a catolé contained 32 specimens of $R$. nasutus, almost all of which were engorged. Several residents of the municipality of Crato reported seeing opossums in the localities studied. These animals probably act as dispersal agents of the parasite and even of triatomines in natural habitats. Catolés presented the second highest number of triatomines, with almost all of them harbouring specimens of reptiles and amphibians.

There have been suggestions that $R$. nasutus is becoming adapted to artificial habitats. During the present study, specimens were frequently collected in such ecotopes (including some infected with $T$. cruzi), confirming these reports by the PCDCh.

Sarquis et al. (2004) suggested that the presence of $R$. nasutus in dwellings was due to the proximity of palms, as insects on the trees are attracted to light and invade houses in search of blood. This has been observed in the Amazon for R. brethesi, 1919 (Coura et al. 1994).

Several studies have demonstrated bloodmeal preferences of triatomines in wild and artificial habitats, enabling evaluation of triatomine feeding behaviour to become an important tool in studies of Chagas disease epidemiology. Some triatomine species are associated with only a few bloodmeal sources, while others are highly promiscuous. Diotaiuti and Dias (1984) analysed bloodmeals of $R$. neglectus captured in macaúba palms near Belo Horizonte and found blood from a wide variety of hosts, including cold-blooded animals, birds and mammals (including man). However, bird blood was most prevalent in meals of $R$. neglectus. Barretto (1979) used the preciptin test to identify the bloodmeals of triatomines from several palm species and found that opossums, bats and rodents were the most important 
sources, all of which are also important carriers of trypanosomatids. Although precipitin testing of samples was performed against the antisera of dog, cat, human, pig, rodent, opossum and bird, only the last two hosts could be identified from bloodmeals of triatomines captured in the five palm species studied. All antisera reacted to the respective homologous sera diluted to at least 1:10.000 and did not react to heterologous sera diluted to $1: 10$, demonstrating the high sensitivity of the technique. Fifty-two specimens did not react with any antiserum, suggesting that they had fed on other vertebrates not included in the battery of antisera employed. The possibility of predation by $R$. nasutus should not be completely discounted, with insects feeding on the haemolymph of other arthropods of the palm biocenose, as has been observed for other species of triatomines (Lent \& Wygodzinsky 1979, Salvatella et al. 1994, Sandoval et al. 2000). One important observation from the present study was the high number of insects with insufficient blood for analysis, which may be related to the scarcity of vertebrate hosts in the palms. Bats are likely important bloodmeal sources for triatomines in palms of Chapada do Araripe. These animals were only completely absent from catolés and were always found in buritis, with more than 30 counted in a single palm.

Our findings confirm that palms in Chapada do Araripe support large $R$. nasutus populations. The triatomine density is high, particularly in babaçus and catolés. Together with PCDCh records, these findings demonstrate the importance of the area for sylvatic $T$. cruzi transmission. In addition to domestic colonisation by triatomines (Martins 1968), alternative forms of T. cruzi transmission, such as house invasion without colonisation as reported from the Brazilian Amazon (Coura et al. 1994) and Ecuador (Aguilar et al. 1999) should be investigated to improve epidemiological vigilance of Chagas disease in Chapada do Araripe, as proposed by Sarquis et al. (2004).

\section{ACKNOWLEDGEMENTS}

To Rogério Bertani, PhD, and Marcelo Ribeiro Duarte, for identifying animals associated with palms, and personnel of the Ceará State Health Service, for help in collecting triatomines.

\section{REFERENCES}

Abad-Franch F, Paucar A, Carpio C, Cuba-Cuba CA, Valente MA, Miles MA 2001. Biogeography of Triatominae (Hemiptera: Reduviidae) in Ecuador: implications for the design of control strategies. Mem Inst Oswaldo Cruz 96: 611-620.

Aguilar HM, Abad-Franch F, Racines J, Paucar A 1999. Epidemiology of Chagas disease in Ecuador. A brief review. Mem Inst Oswaldo Cruz 94: 387-393.

Alencar JE 1987. Historia natural da doença de Chagas no Estado do Ceará. Universidade Federal do Ceará, Fortaleza, 341pp.

Bagnoli E 1998. Projeto Araripe - $1^{\text {a }}$ parte: Conhecendo o Araripe: Atividades produtivas da população. Turismo, Ecoturismo, Turismo Cultural e Científico. In Projeto Araripe. [s.i]: [s.n.], p. 292-318.

Bar ME, Wisnivesky-Colli C 2001. Triatoma sordida Stål 1859 (Hemiptera: Reduviidae: Triatominae) in palms of Northeastern Argentina. Mem Inst Oswaldo Cruz 96: 895-899.
Barretto MP 1979. Epidemiologia. In Z Brener, Z Andrade, Trypanosoma cruzi e Doença de Chagas. Guanabara Koogan, Rio de Janeiro, p. 89-151.

Bérenger JM, Blanchet D 2007. A new species of the genus Panstrongylus from French Guiana (Heteroptera: Reduviidae: Triatominae). Mem Inst Oswaldo Cruz 102: 773-736.

Carcavallo RU, Curto de Casas SI, Sherlock IA, Galíndez-Girón I, Jurberg J, Galvão C, Mena Segura CA, Noireau F 1998. Distribution geographical e dispersão altitudinal. In RU Cacavallo, I Galíndez Girón, J Jurberg, H. Lent, orgs., Atlas of Chagas' disease vector in the Americas, Editora Fiocruz, Rio de Janeiro, Vol. III, p. 747-792.

Costa J, Argolo A, Felix M 2006. Redescription of Triatoma melanica Neiva \& Lent, 1941, new status (Hemiptera: Reduviidae: Triatominae). Zootaxa 1385: 47-58.

Costa J, Felix M 2007. Triatoma juazeirensis sp. nov. from the state of Bahia, Northeastern Brazil (Hemiptera: Reduviidae: Triatominae). Mem Inst Oswaldo Cruz 102: 87-90.

Coura JR, Barrett TV, Arboleda MN 1994. Ataque de populações humanas por triatomines silvestres no Amazonas: uma nova forma de transmissão da infecção chagásica? Rev Soc Bras Med Trop 27: 251-253.

D’Alessandro A, Hincapie O 1986. Rhodnius neivai: a new experimental vector of Trypanosoma rangeli. Am J Trop Med Hyg 35: 512-514.

Dias FBS, Diotaiuti L, Romanha AJ, Bezerra CM, Machado EMM 2007. First report on the occurrence of Trypanosoma rangeli Tejera, 1920 in the state of Ceará, Brazil, in naturally infected triatomine Rhodnius nasutus Stål, 1859 (Hemiptera: Reduviidae: Triatominae). Mem Inst Oswaldo Cruz 102: 643-645.

Diotaiuti L, Dias JCP 1984. Occorrência e biologia do Rhodnius neglectus Lent, 1954 em macaubeiras da periferia de Belo Horizonte-MG. Mem Inst Oswaldo Cruz 79: 293-301.

Diotaiuti L, Lorenzo MG, Dias FBS, Bezerra CM, Garcia MH, Paula AS 2005. Influência da espécie de palmeira sobre o tamanho de Rhodnius nasutus (Stål, 1859) provenientes de carnaúbas ou babaçus do Ceará, Brazil. Rev Soc Bras Med Trop 38 (Suppl. I): 44.

Forero D, Weirauch C, Baena M 2004. Synonymy of the reduviid (Hemiptera: Heteroptera) genus Torrealbaia (Triatominae) with Amphibolus (Harpactorinae), with notes on Amphibolus venator (Klug, 1830). Zootaxa 670: 1-12.

Galvão C, Angulo VM 2006. Belminus corredori, a new species of Bolboderini (Hemiptera: Reduviidae: Triatominae) from Santander, Colombia. Zootaxa 1241: 61-68.

Galvão C, Carcavallo R, Rocha DS, Jurberg J 2003. A checklist of the current valid species of the subfamily Triatominae Jeannel, 1919 (Hemiptera: Reduviidae) and their geographical distribution, with nomenclatural and taxonomic notes. Zootaxa 202: 1-36.

Gamboa J 1961. Comprobación de Rhodnius prolixus extradoméstico. Bol Inf Dir Malar San Amb 1: 139-142.

Gaunt M, Miles M 2000. The ecotopes and evolution of triatomine bugs (Triatominae) and their associated Trypanosomes. Mem Inst Oswaldo Cruz 95: 557-565.

Gurgel-Gonçalves R, Duarte MA, Ramalho ED, Palma ART, Romaña CA, Cuba-Cuba CA 2004. Spatial distribution of Triatominae populations (Hemiptera: Reduviidae) in Mauritia flexuosa palm trees in Federal District of Brazil. Rev Soc Bras Med Trop 37: 241-247.

Henderson A, Galeano G, Bernal R 1995. Field guide to the palms of the Americas, Princeton University Press, Princeton, $352 \mathrm{pp}$. 
Lent H, Wygodzinsky P 1979. Revision of the Triatominae (Hemiptera, Reduviidae), and their significance as vectors of Chagas' disease. Bull Amer Mus Nat Hist, 163: 520.

Lorenzi H, Souza HM, Cerqueira LSC, Medeiros-Costa JT, Ferreira E 2004. Palmeiras brasileiras e exóticas cultivadas. Ed. Plantarum, Nova Odessa, 416 pp.

Lorenzi H, Souza HM, Medeiros-Costa JT, Cerqueira LSC, Behr N 1996. Palmeiras no Brasil: nativas e exóticas. Ed. Plantarum, Nova Odessa, 303 pp.

Lorenzo MG, Minoli AS, Lazzari CR, Paula AS, Diotaiuti L 2003. O microclima dos ecótopos naturais das espécies do gênero Rhodnius no município de Tocantinópolis, estado de Tocantins, Brasil. Rev Soc Bras Med Trop 36 (Suppl. I): 425.

Lucena DT, Lima-Borba H 1977. Panstrongylus megistus leucofasciatus Lucena, 1959 e Rhodnius nasutus Stål, 1859, (Hemiptera: Triatominae) em Pernambuco, Brasil. Rev Inst Med Trop São Paulo 19: 332-334.

Martínez E, Chávez T, Sossa D, Aranda R, Vargas B, Vidaurre P 2007. Triatoma boliviana spp. $\mathrm{n}$. de los valles subandinos de La Paz, Bolívia (Hemiptera: Reduviidae: Triatominae), similar a Triatoma nigromaculata Stål, 1859. Bol Inst Invest Salud y Desarrollo 3: 1-11.

Martins AV 1968. Epidemiologia da doença de Chagas. In JR Cançado, Doença de Chagas, Imprensa Official, Belo Horizonte, p. 223-237.

Noireau F, Abad-Franch F, Valente SAS, Dias-Lima A, Lopes CM, Cunha V, Valente VC, Palomeque FS, Ccarvalho-Pinto CJ, Sherlock I, Aguilar M, Steindel M, Grisard EC, Jurberg J 2002. Trapping Triatominae in silvatic habitats. Mem Inst Oswaldo Cruz 97: 61-63.

Pifano F 1973. La dinamica epidemiológica de la enfermidad de Chagas' en el Valle de los Naranjos, Estado Carabobo, Venezuela. Arch Ven Med Trop Paras Med 2: 3-29.

Romaña CA, Pizarro JC, Rodas E, Guilbert E 1999. Palm trees as ecological indicators of risk areas for Chagas' disease. Trans Royal Soc Trop Med Hyg 93: 594-595.
Salvatella R, Calegari L, Basmadjian Y, Rosa R, Guerrero J, Martinez M, Mendaro G, Briano D, Montero C, Wisnivesky-Colli C 1994. Feeding pattern of Triatoma rubrovaria (Blanchard, 1843) (Hemiptera: Triatominae) in peridomiciliary habitats, of a rural area of Uruguay. Rev Inst Med Trop S Paulo 36: 311-320.

Sanchez-Martin MJ, Feliciangeli MD, Campbell-Lendrum D, Davies CR 2006. Could the Chagas' disease elimination programme in Venezuela be compromised by reinvasion of houses by sylvatic Rhodnius prolixus bug populations? Trop Med Int Health 11: 1585-1593.

Sandoval CM, Joya MI, Gutierrez R, Angulo VM 2000. Cleptohaematophagy of the Triatomine bug Belminus herreri. Med Vet Entom 14: 100-101.

Sarquis O, Borges-Pereira J, Mac Cord, JR, Gomes TF, Cabello PH, Lima MM 2004. Epidemiology of Chagas' disease in Jaguaruana, Ceará, Brazil. I. Presence of triatomines and index of Trypanosoma cruzi infection in four localities of a rural area. Mem Inst Oswaldo Cruz 99: 263-270.

Sarquis O, Sposina R, Oliveira TG, Mac Cord JR, Cabello PH, BorgesPereira J, Lima MM 2006. Aspects of peridomiciliary ecotopes in rural areas of Northeastern Brazil associated to triatomine (Hemiptera: Reduviidae) infestation, vectors of Chagas disease. Mem Inst Oswaldo Cruz 101: 143-147.

Silva IG, Silva HHG 1989. Influência da temperatura na biologia de triatomines. XI. Rhodnius nasutus Stål, 1859 (Hemiptera: Reduviidae). Mem Inst Oswaldo Cruz 84: 377-382.

Silveira AC, Feitosa VR, Borges R 1984. Distribuição de triatomíneos capturados no ambiente domiciliar, no período de 1795/1983, Brazil. Rev Bras Malar Doenças Trop 36: 15-312.

Siqueira AF 1960. Estudos sobre a reação de precipitina aplicada à identificação de sangue ingerido por triatomíneos. Rev Inst Med Trop São Paulo 2: 41-53.

Teixeira ARL, Monteiro OS, Rebelo JM, Argañaraz ER, Vieira D, Lauria-Pires L, Nascimento R, Vexenat CA, Silva AR, Ault SK, Costa JM 2001. Emerging Chagas' disease: yrophic network and cycle of transmission of Trypanosoma cruzi from palm trees in the Amazon. Emerg Infect Dis 7: 100-112. 